\title{
Anterior servikal diskektomi ve füzyon yapılan hastaların klinik ve radyolojik bulgularının pre/postoperatif dönemlerde retrospektif olarak değerlendirilmesi
}

\author{
Retrospective evaluation of clinical and radiological findings of patients who \\ underwent anterior cervical discectomy and fusion in pre/postoperative periods
}

\author{
Ümit Akın Dere, Ömer Hakan Emmez
}

Gönderilme tarihi:12.07.2021

Kabul tarihi:23.08.2021

\section{Öz}

Amaç: Servikal disk hernilerinde altın standart tedavi yöntemi olarak kabul edilen anterior servikal diskektomi ve içi demineralize kemik matriks ile dolu polyether-ether-ketone (PEEK) kafes ile füzyon uygulanan hastaların cerrahi sonuçları değerlendirilerek, günümüzde popüler olan disk artroplastisi gibi cerrahi tekniklerle literatür taraması eşliğinde karşılaştırılmıştır.

Gereç ve yöntem: Ağustos 2011 ile Nisan 2015 tarihleri arasında opere edilen 347 hastanın, retrospektif olarak yapılan nörolojik muayenelerinin, klinik bulgularının, ağrı ve yaşam kalitesi skalaları ve 142 hastanın pre/ postoperatif radyolojik bulguları değerlendirilmiştir.

Bulgular: Hastaların ortalama yaşı 46,7 $\pm 9,4$ (min 23-maks 75), 165’i (\%47,6) erkek, 182'si (\%52,4) kadın olarak tespit edilmiştir. Tek seviye diskektomi ve füzyon yapılan 229 hasta (\%66); iki seviye diskektomi ve füzyon yapılan 112 hasta (\%32,3); 3 seviye diskektomi ve füzyon yapılan 6 hasta $(\% 1,7)$ olarak tespit edilmiştir. Hastaların ortalama takip süreleri 16 $\pm 11,7$ aydır (min3 ay-maks 46 ay). Toplam 14 (\%4) hastada postoperatif komplikasyon tespit edilmiş olup bunlardan sadece ikisinde (kozalji ve motor güç kaybı olan hastalar) şikayetler tam olarak düzelme göstermemiştir.

Sonuç: Çalışmamız, servikal disk hastalığının tedavisinde eski ve yeni birçok yöntemle karşılaştırıldığında, ASDF yönteminin günümüzde altın standart tedavi olduğunu desteklemektedir. Gerek klinik skalalar gerekse radyolojik kriterler göz önüne alındığında yüksek hasta memnuniyeti, etkinlik ve güvenlik sağladığı görülmektedir.

Anahtar kelimeler: Servikal diskektomi, PEEK kafes, servikal aks.

Dere ÜA, Emmez ÖH. Anterior servikal diskektomi ve füzyon yapılan hastaların klinik ve radyolojik bulgularının pre/postoperatif dönemlerde retrospektif olarak değerlendirilmesi. Pam Tıp Derg 2022;15:59-68.

\begin{abstract}
Purpose: The surgical results of patients who underwent anterior cervical discectomy, which is accepted as the gold standard treatment method in cervical disc hernia, and fusion with polyether-ether-ketone (PEEK) cage filled with demineralized bone matrix, were evaluated and compared with today's popular surgical techniques such as disc arthroplasty, accompanied by a literature review.

Materials and methods: Retrospective neurological examinations, clinical findings, pain, and quality of life scales of 347 patients operated between August 2011 and April 2015, and pre/postoperative radiological findings of 142 patients were evaluated.

Results: The mean age of the patients was 46.7 \pm 9.4 (min 23-max 75), 165 (47.6\%) male, $182(52.4 \%)$ female. Two hundred twenty-nine patients $(66 \%)$ underwent single-level discectomy and fusion; 112 patients $(32.3 \%)$ underwent two-level discectomy and fusion; six patients $(1.7 \%)$ underwent three levels of discectomy and fusion. The mean follow-up period of the patients was $16 \pm 11.7$ months (min 3 months-max 46 months). Postoperative complications were detected in a total of $14(4 \%)$ patients, and only two of them (patients with causalgia and loss of motor power) did not show complete improvement.

Conclusion: Our study supports that the anterior cervical discectomy and fusion method is currently the goldstandard treatment compared with many old and new methods in treating cervical disc disease. Considering both clinical scales and radiological criteria, ASDF provides high patient satisfaction, efficacy, and safety.
\end{abstract}

Key words: Cervical discectomy, PEEK cage, cervical axis.

Dere UA, Emmez OH. Retrospective evaluation of clinical and radiological findings of patients who underwent anterior cervical discectomy and fusion in pre/postoperative periods. Pam Med J 2022;15:59-68.

Ümit Akın Dere, Dr. Öğr. Üye. Pamukkale Üniversitesi Tıp Fakültesi, Beyin ve Sinir Cerrahisi Anabilim Dalı, Denizli, Türkiye, e-posta: umitakindere@gmail.com (https://orcid.org/0000-0002-6678-6224) (Sorumlu Yazar)

Ömer Hakan Emmez, Prof. Dr. Gazi Üniversitesi Tıp Fakültesi, Beyin ve Sinir Cerrahisi Anabilim Dalı, Ankara, Türkiye, e-posta: hakanemmez@ gmail.com (https://orcid.org/0000-0002-3290-179X) 


\section{Giriş}

Servikal disk hernisinin (SDH) insidansı 100.000 kişide 18,6 olup hastalığın insidansı 6. dekatta artmaktadır. Hastalığın etiyolojisinde ise, erkek cinsiyet, sigara kullanım öyküsü, ağır yük kaldırma, dalış gibi sporlar ve mesleki faktörler ön plana çıkmaktadır [1]. En sık görülen disk hernisi seviyesi C5-6 olarak tespit edilmiştir. Bunu C4-5 ve C6-7 seviyeleri izlemiştir [2].

1950'lerde Cloward ve Smith-Robinson tarafından anterior servikal diskektomi (ASD) ve füzyon (ASDF) tekniği tanımlanmıştır [3]. $\mathrm{Bu}$ dönemde füzyon amacı ile boşaltılan mesafeye kemik grefti konmuştur. Hirsch, 1964 yılında bütün SDH hastalarında füzyonun gerekli olmadığını, sadece diskektominin yeterli olabileceğini gösteren vaka serisini yayınlamıştır [4]. 1970 yılına gelindiğinde ise Caspar ve ark. [5] servikal diskektomiye internal fiksasyon ve enstrümantasyon tekniğini eklemişlerdir.

Servikal disk herniyasyonunun cerrahi tedavisinde ASDF uzun zamandır kullanılan, etkinliği ve güvenilirliği kanıtlanmış bir yöntemdir. Ancak ameliyat sonrası dönemlerde karşılaşılan komşu segment hastalığı (KSH), buna ikincil gerek duyulan cerrahiler ve segmentin hareketini koruma amacıyla geliştirilen disk protezleri SDH tedavisinde gündemde olan tartışma konularıdır [6-8].

Cerrahi tedavide amaç, herniye diski ve varsa osteofitin neden olduğu omurilik ve/ veya kök basısını ortadan kaldırmak ve hem radiküler semptomları azaltabilmek hem de omurga stabilizasyonunu sağlamak amacı ile disk mesafesinin yüksekliğini koruyacak biçimde füzyon gelişimini sağlamak olmalıdır. $\mathrm{Bu}$ çalışmada, SDH nedeniyle ASDF işlemi yapılan hastalar, cerrahi öncesi ve sonrası, klinik ve radyolojik bulguları ile retrospektif olarak değerlendirilmiş ve ASDF işleminin etkinliği, komşu segment hastalığı, servikal aks bozuklukları, füzyon başarısı ve servikal disk protezi uygulaması gibi güncel uygulamalar literatür eşliğinde tartışılmıştır.

\section{Gereç ve yöntem}

\section{Hasta popülasyonu}

Bu çalışmada Ağustos 2011 ile Nisan 2015 tarihleri arasında tek seviye, komşu ya da farklı segment iki seviye ve nadir olarak üç seviye diskektomi ve füzyon yapılmış olan 347 hasta retrospektif olarak değerlendirilmiştir.

Hastalar ile yapılan görüşmeler ve radyolojik görüntüler hastalardan alınan onamlar sonrasında kayıt altına alınmış olup 2019 tarihinden önce yapılmış retrospektif bir çalışma olması sebebi ile etik kurul alınması gerekliliği doğmamıştır.

$\mathrm{Bu}$ hastalardan klinik ve radyolojik bilgileri elde edilebilen 142 hastanın ameliyat öncesi dönem, erken ve geç ameliyat sonrası dönem radyolojik görüntüleri incelenmiştir. Hastaların bir kısmı ile yüz yüze görüşerek, bir kısmı ile telefonda görüşerek hem ameliyat öncesi hem ameliyat sonrası VAS (Visual Analog Scale), SF-36 ve NDI (Neck Disability Index) skorları ölçülmüştür. VAS yönteminde ağrılarının 0-10 arası (hiç ağrı olmaması: 0 - hayatındaki en şiddetli ağrı olması: 10) puanlama yapılmıştır.

NDI, Howard Vernon [9] tarafından 1989 yılında Oswestry Low Back Pain Disability Index yeniden düzenlenerek geliştirilmiştir. On bölümden oluşur ve hastalığın ağrı bileşeninin günlük yaşama etkilerini değerlendirir. Puanlama 0-50 arasındadır. 0 puan en iyi, 50 puan en kötü sonucu bildirir. 0-4 puan, yetersizlik olmadığını; 5-14 puan, hafif şiddette yetersizliği; 15-24 puan, orta şiddette yetersizliği; 25-34 puan, ciddi yetersizliği; 35 puan ve üstü, tam yetersizliği ifade etmektedir.

SF-36 ölçeği, hastalığın yaşam kalitesi üzerindeki etkilerini değerlendirmek üzere Ware ve ark. [10] tarafından geliştirilmiştir. Ölçek yaş, hastalık veya herhangi bir tedavi grubuna spesifik değildir. Ölçek 36 maddeden oluşur ve 8 sağlık kavramını kapsamaktadır: ağrı, fiziksel fonksiyon, fiziksel problemlerin neden olduğu yaşamsal kısıtlanmalar, mental sağlık, canlııık/ enerji, sosyal fonksiyon, duygusal problemlerin neden olduğu yaşamsal kısıtlanmalar ve genel sağlık. Her sağlık kavramı için sorular kodlanmıştır ve puanlanmasında 0 (en kötü) 100 (en iyi) arası dağılım gösterir.

Yaş, cinsiyet, seviye, şikayet, nörolojik muayene gibi demografik özellikler 347 hastada incelenirken, radyolojik incelemeler ve bunlarla ilgili değişkenlerin analizi ise 142 hastada uygulanabilmiştir. Cerrahi endikasyon kriterleri motor güç kaybı, uzun trakt bulgularının olması, medikal tedaviye dirençli şiddetli akut radiküler ağrı, en az üç haftalık konservatif tedaviye 
rağmen geçmeyen ya da şiddetlenen radiküler ağrı ve semptom ve bulgularının görüntüleme yöntemleri ile örtüşmesi olarak belirlenmiştir.

İleri derecede spondilozu, servikal travmaya bağlı oluşan diskopatisi olan, ikinci kez servikal operasyon öyküsü olan ve anterior plak uygulanan hastalar çalışmaya dahil edilmemişlerdir.

Hastaların takiplerinde, ameliyat sonrası 1. gün ile ortalama 16. ayda yapılmış olan kontrol nörolojik muayeneleri ve direkt grafileri incelenmiştir. Olguların ameliyat öncesi ve ameliyat sonrası servikal grafilerinde, disk mesafesi yüksekliğindeki değişiklikler, servikal aksın ve segmental açılanmanın ölçümleriyle servikal aksta düzleşme veya anterior açılanma, komşu segmentlerdeki değişiklikler ve füzyonda kullanılan malzeme ile ilgili sorunlar değerlendirilmiştir.

Servikal aks değerlendirilirken, Cobb Metodu ya da Harrison'un Posterior Tanjant Metodu kullanılarak aks açısı $<0^{\circ}$ ise kifoz, $0^{\circ}-10^{\circ}$ arası ise düz, $>10^{\circ}$ ise lordoz olarak kabul edilmiştir. Segmental açılanma değerlendirilirken ise diskektomi uygulanan mesafenin üstündeki korpusun posterior sınırı ile altındaki korpusun posterior sınırından geçen doğruların oluşturduğu açı (segmental açı) ölçülerek, bu açı $<0^{\circ}$ ise kifoz, açı $\geq 1^{\circ}$ ise lordoz olarak kabul edilmiştir [11].

\section{İstatistiksel analiz}

İstatistiksel analizler SPSS 15.0 yazılımı kullanılarak yapılmıştır. Değişkenlerin normal dağılıma uygunluğu görsel ve analitik yöntemlerle (Kolmogorov-Smirnov/ShapiroWilk Testleri) incelenmiştir. Tanımlayıcı analizler normal dağılmayan değişkenler için Wilcoxon Testi kullanılarak, normal dağılıma uygun olan değişkenler için Eşleştirilmiş t-Test kullanılarak yapılmıştır. Kategorik değişkenler için Pearson Ki-Kare, Yates Düzeltmeli Ki-Kare ve Fisherin Kesin Testi kullanılmıştır. Bağımlı ölçümlerde ise Mcnemar Testi kullanılmıştır. Nörolojik muayene sonucu ile yaş arasındaki değişim için ANOVA testi kullanılmıştır. Korelasyon bakılan değişkenlerin normal dağılıma uymadığı gözlendiği için Spearman testi kullanılmıştır. İstatistiki ölçümlerde, ' $p$ ' değerinin 0,05 'in altında olduğu durumlar istatistiksel olarak anlamlı sonuçlar şeklinde değerlendirilmiştir.

\section{Bulgular}

347 hastanın ortalama yaşı $46,7 \pm 9,4$ ( $\mathrm{min}: 23$ maks:75) ve 165 'i $(\% 47,6)$ erkek, 182 'si $(\% 52,4)$ kadın olarak tespit edilmiştir. Erkek hastaların yaş ortalaması $47,53 \pm 9,20$ olarak görülürken kadın hastaların yaş ortalaması $46,05 \pm 9,55$ olarak tespit edilmiştir. Tek seviye diskektomi ve füzyon yapılan 229 hasta (\%66); iki seviye diskektomi ve füzyon yapılan 112 hasta (\%32,3); 3 seviye diskektomi ve füzyon yapılan 6 hasta $(\% 1,7)$ olarak tespit edilmiştir. En sık olarak C5-6 $(\% 59,4)$ intervertebral disk seviyesine müdahale edildiği tespit edilmiştir. Tek seviye diskektomi yapılan hastalardan, kadınlarda C5-6 disk hernisi daha fazla görülürken erkeklerde C6-7 disk hernisi daha fazla görülmüştür. (Tablo 1) İki seviye diskektomi yapılan hastalarda ise en sık olarak C5-6/C6-7 seviyeleri görülmüş olup kadın ile erkek arasında istatistiksel olarak bir fark saptanmamıştır. Diskektomi yapılan tüm seviyeler ile cinsiyetler arasında yapılan istatistiksel karşılaştırmalarda ise C5-6 disk hernisinin kadınlarda; C3-4 ve C6-7 disk hernisinin ise erkeklerde istatistiksel olarak daha sık görüldüğü tespit edilmiştir $(p<0,005)$.

Hastaların \%78,4'ünde radiküler tipte ağrı şikayeti tespit edilmiştir. Hastaların 260'ında (\%75) motor kayıp, duyu kusuru ya da spinal kord hasarına bağlı patolojik refleks tespit edilmişken 87 (\%25) hastada herhangi bir nörolojik kusur izlenmemiştir. Nörolojik kusuru olan 260 hastadan \%93'ünde duyu kusuru tespit edilirken, motor kusur $\% 75$ hastada tespit edilmiştir. Derin tendon refleks (DTR) kaybı ise $\% 50$ hastada görülmüştür. (Tablo 1 ) Nörolojik muayenelerinde patolojik refleks tespit edilen hastaların nörolojik kusuru olmayan ya da motor/duyu kaybı olan hastalara oranla daha ileri yaşta $(51,63 \pm 10,40)$ oldukları görülmüştür $(p<0,05)$.

Hastaların ameliyat oldukları disk mesafesine göre nörolojik muayeneleri karşılaştırıldığında C6-7 seviyesinde disk hernisi olan hastalarda istatistiksel olarak anlamlı derecede daha sık nörolojik kusur tespit edilmiştir $(p<0,05)$. C6-7 disk hernisi olan hastaların sol radiküler şikayetlerinin istatistiksel olarak anlamlı şekilde fazla olduğu tespit edilmiştir $(p<0,05)$. Bunun yanı sıra iki veya daha fazla seviye $\mathrm{SDH}$ nedeni ile ameliyat olan hastalarda patolojik reflekslerin istatistiksel olarak anlamlı şekilde daha sık görüldügü tespit edilmiştir $(p<0,05)$. 
Tablo 1. Hastaların demografik bilgileri

\begin{tabular}{|c|c|}
\hline Hasta sayısı & 347 \\
\hline Yaş & $\begin{array}{l}46,7 \pm 9,4 \\
K: 46,05 \pm 9,55 \\
E: 47,53 \pm 9,20\end{array}$ \\
\hline Cinsiyet & $\begin{array}{l}\mathrm{E}: 165(\% 47,6) \\
\mathrm{K}: 182(\% 52,4)\end{array}$ \\
\hline Tek seviye diskektomi + füzyon & $229(\% 66)$ \\
\hline C5-6 & $\begin{array}{l}\mathrm{E}: 32 \\
\mathrm{~K}: 70\end{array}$ \\
\hline C6-7 & $\begin{array}{l}\mathrm{E}: 48 \\
\mathrm{~K}: 33\end{array}$ \\
\hline İki seviye diskektomi + füzyon & $112(\% 32,3)$ \\
\hline Üç seviye diskektomi + füzyon & $6(\% 1,7)$ \\
\hline Disk seviyeleri & $\begin{array}{l}\text { C2-3: } 3(\% 0,9) \\
\text { C3-4: } 24(\% 6,9) \\
\text { E: } 18 \text { K: } 6(p<0,05) \\
\text { C4-5: } 71(\% 20,5) \\
\text { C5-6: } 206(\% 59,4) \\
\text { E: } 81 \mathrm{~K}: 125(p<0,05) \\
\text { C6-7: } 166(\% 47,8) \\
\text { E: } 92 \text { K: } 74(p<0,05) \\
\text { C7-T1: } 1(\% 0,3)\end{array}$ \\
\hline Nörolojik muayene & $\begin{array}{l}\text { Radiküler ağrı: }(\% 78,4) \\
\text { Motor kayı: } 242(\% 93) \\
\text { Duyu kusuru: } 195(\% 75) \\
\text { Patolojik refleks: } 36(\% 13,8) \\
\text { DTR kaybı: } 130(\% 50) \\
\text { Normal: } 87(\% 25)\end{array}$ \\
\hline
\end{tabular}

E: erkek, K: kadın, C: servikal, T: torakal

Hastaların şikayetlerini, radiküler ve radiküler olmayan ağrı şeklinde gruplandırdığımızda sol radiküler ağrı şikayeti olan hastalarda nörolojik kusur daha sık saptanırken, radiküler ağrı şikayeti olmayan hastalarda daha sık saptanan patolojik refleks istatistiksel olarak anlamlı bulunmuştur $(p<0,05)$.

Seksen altı $(\% 24,8)$ hasta $0-3$ ay arası, 51 $(\% 14,6)$ hastan 3-6 ay, $36(\% 10,4)$ hasta $6-12$ ay, $60(\% 17,2)$ hasta $12-24$ ay ve $114(\% 32,8)$ hasta 24 aydan uzun, süren şikayetler sonrası ameliyat edilmiştir. Hastaları şikayet sürelerine göre gruplandırdıktan sonra ameliyat öncesi nörolojik muayeneleri ile karşılaştıııldığımız zaman istatistiksel olarak anlamlı fark olmadığı görülmüştür $(p>0,05)$.

Yetmiş $(\% 20,2)$ hasta ameliyat öncesi dönemde fizik tedavi almış iken, ameliyat sonrası dönemde fizik tedavi intiyacı olan 15
$(\% 4,3)$ hasta tespit edilmiştir. Özellikle ameliyat sonrası dönemde fizik tedavi intiyacı duyan hastaların boyun ağrısına yönelik VAS (ort. $4,2 \pm 1,08$ ) ve NDI (ort. $8,3 \pm 1,57$ ) skorlarının ameliyat öncesi ve ameliyat sonrası dönemde daha yüksek olduğu görülmüştür.

142 hastanın ortalama $16 \pm 11,7$ aylık takip süresinde, radyolojik değerlendirmede ameliyat öncesi ve ameliyat sonrası servikal aks açısı ya da lordoz açısı (LA); ameliyat öncesi ve ameliyat sonrası segmental açı (SA) ve servikal disk yüksekliği (SDY) ölçümleri değerlendirilmiştir. Servikal aks açıları ameliyat öncesi dönem ile karşılaştırıldığında ameliyat sonrası 1 . günde lordoz açısında azalma izlenirken, ameliyat sonrası geç dönem ölçümlerinde lordoz açısında artış izlenmiştir $(p<0,05)$. Servikal aks açılarını kifoz, düz ve lordoz şeklinde kategorize ettiğimizde ise ameliyat sonrası 6 . aydan sonra lordoz grubunda istatistiksel olarak anlamlı bir 
artış tespit edilmiştir $(p<0,05)$. Segmental açıları da ameliyat öncesi ve ameliyat sonrası dönemde kifoz ve lordoz olarak kategorize ettiğimizde ameliyat sonrası dönemde lordoza yönelimde artış istatistiksel olarak anlamlı bulunmuştur $(p<0,05)$. Hastaların ameliyat öncesi ve ameliyat sonrası servikal disk yükseklikleri karşılaştırıldığında istatistiksel olarak anlamlı şekilde disk yüksekliğinde artış tespit edilmiştir $(p<0,05)$ (Tablo 2).
Hastaların yaş, cinsiyet, seviye ve şikayetleri göz önüne alındığında istatistiksel olarak füzyon oranlarında anlamlı bir fark saptanmamış olup hastaların ameliyat sonrası kontrollerinde füzyon problemi saptanmamıştır $(p>0,05)$. Hastaların ameliyat öncesi ve ameliyat sonrası yapılan VAS, NDI ve SF-36 testlerinin skorları Tablo 3'te yer almaktadır. Hem aksiyel ağrı için hem de radiküler ağrı için bakılan VAS skorlarının ameliyat öncesi döneme göre

Tablo 2. Ameliyat öncesi ve ameliyat sonrası servikal aks açısı ya da lordoz açısı

\begin{tabular}{llllllc}
\hline & & LA & \multicolumn{2}{c}{ SA } & \multicolumn{2}{c}{ SDY } \\
& Ort & Min-Maks & Med & Min-Maks & Ort & Min-Maks \\
\hline Ameliyat öncesi & 14,60 & $-14,40-59,30$ & 1,00 & $-13,60-36,00$ & 4,10 & $2,80-7,00$ \\
Ameliyat sonrası & 17,00 & $-7,60-48,90$ & 1,90 & $-12,20-32,00$ & 4,90 & $3,30-8,10$ \\
\hline
\end{tabular}

(LA); ameliyat öncesi ve ameliyat sonrası segmental açı (SA) ve servikal disk yüksekliği (SDY) ölçümleri sonuçları

Tablo 3. Ameliyat öncesi dönem ve ameliyat sonrası 12. ayda yapılan VAS, NDI ve SF-36 testlerinin skorları

\begin{tabular}{lllllll}
\hline & \multicolumn{2}{c}{ VAS } & \multicolumn{2}{c}{ SF-36 } & \multicolumn{2}{c}{ NDI } \\
& Ort & Min-Maks & Ort & Min-Maks & Ort & SD \\
\hline Ameliyat öncesi & 9 & $7-10$ & 32 & $20-46$ & 30,10 & $\pm 9,50$ \\
Ameliyat sonrası (12.ay) & 1 & $0-4$ & 84 & $64-92$ & 5,14 & $\pm 3,46$ \\
\hline
\end{tabular}

ameliyat sonrası dönemde istatistiksel olarak anlamlı şekilde azaldığı görülmüştür $(p<0,05)$. $\mathrm{Bu}$ azalma radiküler VAS için belirgin olarak daha fazladır. SF-36 skorları incelendiğinde de yaşam kalitesinde çok net bir artış olduğu görülmüştür. Ortalama 32 puandan, 84 puana varan yükseliş izlenmiştir. NDI puanları da VAS ve SF-36 skorlarına paralel biçimde düzelme göstermiştir.

Hastaların ( $n=142)$ ameliyat öncesi ve ameliyat sonrası dönem servikal aks açıları ve VAS (boyun ve kol), NDI, SF-36 skorlarının korelasyonu yapıldığında zayıf ilişkili olarak tespit edilmiş olup istatistiksel olarak anlamlı bulunmamıştır $(p>0,05)$. Hastaların $(n=347)$ yaşları ve cinsiyetleri/ ameliyat oldukları seviye/ semptom süresi ile ağrı ve yaşam kalitesi skorlarının birbirleri arasındaki ilişkilerine bakıldığında istatistiksel olarak anlamlı bir fark bulunmamıştır $(p>0,05)$.

Ameliyat sonrası erken dönemde (2. saat) iki hastada loj içi hematom gelişmesi üzerine tekrar ameliyata alınarak kanama kontrolü sağlanmış olup diskektomi mesafesi ya da füzyon materyali ile ilgili ek bir komplikasyon yaşanmamıştır. Bu iki hastadan bir tanesi aynı gün içinde iki kez loj içi hematom nedeni ile ameliyat edilmiş olup ek sıkıntı yaşanmadan taburculuğu sağlanmıştır.

İki hastada yara yeri ile ilgili ameliyat sonrası erken dönemde (12. gün) enfeksiyon ve yara dudaklarında açılma tespit edilmiş olup ikinci bir cerrahi ile cilt ve cilt altı temizlenerek yeniden sütüre edilmiş, antibiyotik başlanarak tedavisi sağlanmış olup koyulan füzyon materyali ile ilgili ek bir sıkıntı saptanmamıştır.

Bir hastada ameliyat öncesi şikayeti olduğu tarafın kontralateralinde kozalji tarzında şikayeti oluşmuş olup uygun medikal tedavi ile şikayetleri düzelmiştir.

Bir hastada koyulan füzyon materyalinin erken dönem dislokasyonuna bağlı ameliyat sonrası 2. ay yapılan kontrollerinde disfaji şikayeti sonrası ikinci bir cerrahi ile füzyon materyalinin yüksekliği arttırılarak diskektomi mesafesine yerleştirilmesinin ardından anterior servikal plak kullanılarak fiksasyonu sağlanmıştır. 
Bir hastada ise erken ameliyat sonrası dönemde nörolojik muayenede motor kuvvette gerileme tespit edilmiş olup takiplerinde fizyoterapi ile nörolojik muayenede tama yakın düzelme sağlanmış, konulan füzyon materyali ile ilgili ya da cerrahi teknikle ilgili bir komplikasyon tespit edilmemiştir.

6 hastada ameliyat sonrası erken dönemde (1. gün-1. ay) geçici ses kısıklığı izlenmiş olup ek tedaviye gerek duyulmadan takiplerde düzelmiştir. Bu hastalardan 2 tanesinin C3-4, 3 tanesinin C4-5, 1 tanesinin C5-6 seviyesinden ameliyatolduğu görülmüştür. Hastaların ameliyat oldukları seviyeler ile ses kısıklığı şikayetleri arasında anlamlı bir ilişki saptanmamış olup 2-4 aylık takip sonrasında şikayetlerde tama yakın düzelme izlenmiştir.

Bir hastada ise ameliyat sonrası erken dönemde Horner Sendromu gelişmiş olup, takipte şikayetleri 3 ay içerisinde düzelmiştir.

Toplam 14 (\%4) hastada ameliyat sonrası komplikasyon tespit edilmiş olup bunlardan sadece ikisinde (kozalji ve motor güç kaybı olan hastalar) şikayetler tam olarak düzelme göstermemiştir.

Ameliyat sonrası takiplerinde direkt grafileri incelenen 142 hastadan $20(\% 14,1)$ hastada komşu segment dejenerasyonu görülürken, bu hastalardan 6'sının $(\% 4,2)$ semptomatik olduğu ve bunlardan ikisinin $(\% 1,4)$ ameliyat edildiği saptanmıştır.

\section{Tartışma}

Anterior servikal diskektomi ve füzyondan sonra hastalarda en belirgin memnuniyet radiküler semptomlardaki düzelme olup, aksiyel ağrı bazı hastalar için sorun olmaya devam etmektedir. Etiyolojide en çok üzerinde durulan konu, ameliyat sonrası servikal dizilim, füzyon sonrası gelişen hareket kısıtlılığı ve ameliyat öncesi dönemde servikal spondilozdur. Grob ve ark. [12] yapmış olduğu 45 yaş ve üzeri, 107 hastalık seride hastalar randomize olarak aksiyel ağrısı olan $(n=54)$ ve olmayanlar $(n=53)$ şeklinde gruplara ayrılıp bu gruplar birbirleri ile karşılaştırılmıştır. İki grup arasında servikal ve segmental aks açıları açısından, cinsiyetler ayrı ayrı değerlendirildiğinde, istatistiksel olarak anlamlı fark saptanmamıştır. Bu çalışmada sadece kadın hastalarda yaş ile birlikte servikal lordozda artış görülmüştür. Gore ve ark. [13] 10 yıllık takiplerinde ise 205 hasta klinik ve röntgenografik verileri ile değerlendirilmiş olup hastaların ağrı şikayetleri ile röntgenografik bulguları (dejenerasyon, sagittal kanal genişliği ve lordoz açısı) arasında istatistiksel olarak anlamlı fark saptanmamıştır. Çalışmamızda ameliyat sonrası aksiyel ağrıya sebep olabilecek faktörler incelendiğinde hastaların servikal sagittal aks ve segmental aks açıları ölçümleri ile ağrı skorları göz önüne alındığında, aks açılarında saptanan lordotik düzelme ile ağrı şikayetlerinin azalması doğru orantılı olarak saptanmış olmasına rağmen bu durum istatiksel olarak anlamlı bulunmamıştır $(p>0,05)$. Aynı şekilde hasta cinsiyeti ve yaş dağılımı ile aksiyel ağrı arasında da istatistiksel olarak anlamlı bir ilişki saptanmamıştır. Bu verilerden yola çıkarak aksiyel ağrıya neden olabilecek tek bağımsız faktör saptanamamakla birlikte, aks açılarındaki anormallikleri de boyun ağrısının temel nedeni olarak yorumlayamayı.

Literatür ile benzer biçimde bu çalışmada da en sık olarak C5-6 intervertebral disk seviyesine müdahale edildiği izlenmiştir. Bu segmentin en hareketli segment oluşunun, disk hernisi gelişiminde predispozan faktör olduğu iddia edilmektedir [14]. Literatürde bulamadığımız bir ilginç veri ise iki veya daha fazla seviye disk hernisi olan hastalarda patolojik reflekslerin daha sık olduğunun görülmesidir $(p<0,05)$. Bunun sebebinin uzun dönemde oluşan bası etkisi ve buna ikincil gelişen miyelomalazik değişiklikler olabileceğini düşünmekteyiz.

1950'li yılların başında ortaya çıkan ve hızla yaygınlaşan anterior yaklaşım ve otogreft ile füzyon tekniği 1964 yılında Hirsch'in bütün SDH hastalarında füzyonun gerekli olmadığı, sadece diskektominin yeterli olabileceğini gösteren vaka serisini yayınlaması [4] ile yeniden tartışılmaya başlanmıştır. Son zamanlarda yapılan çalışmalarda da aynı tartışma devam etmektedir. Abd Alrahman ve ark. [15] yapmış oldukları çalışmada ASDF yapılan hastalarda ameliyat sonrası memnuniyetin daha fazla olduğunu ve kifoz gelişiminin, sadece diskektomi yapılan hastalarda istatistiksel olarak anlamlı derecede yüksek olduğunu belirtmişlerdir. Ayrıca, ASD (\%64) yapılan hastalarda füzyon oranının ASDF (\%94) yapılan olgulara kıyasla daha yavaş ve düşük oranda olduğunu belirtmişlerdir. Xie ve ark. [16] yapmış oldukları 2 yıl takip süreli çalışmada, ASD ile ASDF arasında klinik olarak bir farklılık olmadığını ancak, segmental aks açısında ASD yapılan olgularda, ASDF ya da 
ASDF ile plak uygulanan olgulara göre daha yüksek oranda kifoz geliştiğini belirtmişlerdir. Ameliyat öncesi röntgenografik incelemelerinde ASD yapılan olgularda segmental kifoz oranı $\% 17$ iken ameliyat sonrası dönemde bu oranın \%75'e yükseldiğini belirtmişlerdir. ASDF ve ASDF ile plak uygulanan olgularda segmental kifozda istatistiksel olarak anlamlı bir değişiklik saptamamışlardır. Ayrıca füzyon oranlarını değerlendirdiklerinde ASD yapılan olgularda $\% 67$, ASDF yapılan olgularda \%93, ASDF ile plak uygulanan olgularda \%100 füzyon gelişimi tespit etmişlerdir.

$\mathrm{Bu}$ çalışmaların aksine sadece ASD yaklaşımının etkin, güvenilir ve daha az maliyetli olduğunu öne süren çalışmalarda mevcuttur. Savolainen ve ark. [17] yapmış olduğu prospektif 91 hasta içeren, tek seviye servikal disk hernisi olan, 4 yıl takip süreli çalışmalarında ASD, ASDF (otolog kemik grefti) ve ASDF ile birlikte plak uygulanan hastalar değerlendirilmiştir. Kifoz gelişimi ASD grubunda \%62,5, ASDF grubunda $\% 40$, ASDF ile plak grubunda ise $\% 44$ olarak bulunmuştur. Odom kriterlerine göre yapılan değerlendirmede ise sonuçlar, ASD grubunda \%76, ASDF grubunda \%82, ASDF ile plak grubunda ise $\% 73$ oranında "iyi" olarak saptanırken sırası ile $\% 0, \% 4$ ve $\% 4$ oranlarında da 'kötü' sonuç tespit etmişlerdir. Sonuç olarak üç farklı cerrahi yöntem arasında istatistiksel olarak anlamlı fark tespit etmedikleri gibi aynı zamanda tek seviye SDH olan olgularda sadece diskektomi yapılmasının yeterli olacağını belirtmişlerdir. Yapmış olduğumuz literatür taramasında da benzer nitelikte çalışmalar mevcuttur [18, 19]. Bizim çalışmamızda ameliyat sonrası servikal aks (ameliyat öncesi $14,60^{\circ} \pm 2,2$ ameliyat sonrası $21,43^{\circ} \pm 8,27^{\circ}$ ) ve segmental aks (ameliyat öncesi $1,00^{\circ} \pm 0,17^{\circ}$ ameliyat sonrası $1,90^{\circ} \pm 0,22^{\circ}$ ) açılarının lordotik yönde artış gösterdiği; disk mesafe yüksekliklerinin ise (ameliyat öncesi 4,10 $\pm 0,22 \mathrm{~mm}$, ameliyat sonrası $4,90 \pm 0,25 \mathrm{~mm}$ ) istatistiksel olarak anlamlı derecede arttığı görülmüştür $(p<0,05)$. Ortalama 16 ay süreli takiplerde füzyon gelişimi tüm hastalarda izlenirken ağrı ve yaşam kalite ölçeklerinde de istatistiksel olarak anlamlı derecede düzelme tespit edilmiştir $(p<0,05)$.

Smith ve Robinson [20], anterior servikal füzyonda \%12 oranında başarısızlık olduğunu, füzyon uygulanan mesafe sayısı arttıkça ters orantılı olarak füzyon başarı oranının da azaldığını ifade etmişlerdir. Tek mesafe diskektomi yapılan hastalar için füzyon başarı oranını \%94, iki mesafe diskektomi yapılan hastalarda bu oranı $\% 73$, üç mesafe diskektomi yapılan hastalar için ise \%50 olarak saptamışlardır. Samartzis ve ark. [21] yapmış olduğu 45 yaş ortalamasına sahip 69 hastalık, tek seviye servikal diskektomi yapılan serilerinde, 38 hastaya sadece ASDF (trikortikal otogreft) yapılmışken, 31 hastaya ASDF ile birlikte servikal plakla fiksasyon uygulanmıştır. Ortalama 14 ay takip sonrasında $66(\% 95,7)$ hastada (ASDF \%100, ASDF ile plak \%90,3) füzyon izlenmiştir. İki grup arasında istatistiksel olarak füzyon gelişimi açısından anlamlı fark saptamamışlardır. Plak uygulanan hastaların \%9,7'sinde revizyon amaçlı ikincil cerrahi yapılırken, sadece ASDF uygulananlarda ikincil cerrahi gereksinim olmamıştır. Ameliyat sonrası klinik değerlendirmelerinde iki grup arasında istatistiksel olarak anlamlı fark bulunmamıştır. $\mathrm{Bu}$ veriler ışığında bizim yapmış olduğumuz cerrahi yöntemde otolog kemik grefti yerine PEEK kafesler kullanmamız neticesinde füzyon materyalinin çökmesine bağlı servikal disk mesafesinde yükseklik kaybı ya da füzyon gelişimi ile ilgili bir problem izlenmemiş olup, erken ameliyat sonrası dönemden itibaren hastalarda belirgin klinik ve radyolojik düzelme izlenmiştir. Sadece bir hastamızda PEEK kafesin dislokasyonuna bağlı disfaji şikayeti olması üzerine ameliyat sonrası 2. haftada ikincil cerrahi ile kafes değiştirilmiş ve anterior servikal plak ile fiksasyon sağlanmıştır. Anterior servikal diskektomi sonrası füzyon amacıyla intervertebral aralığa yerleştirilen kafesler, günümüzde kolay uygulanışı, fizyolojik disk yüksekliğini korumaları, distraksiyon sağlamaları, aksiyel instabiliteyi düzeltmeleri ve kemik greftle füzyon amaçlanan cerrahilerde artan komplikasyonlar nedeniyle, ilk tercihimiz olmuşlardır.

Teramoto [22] ve Goffin [23] tarafından yapılan çalışmalarda ASDF yapılan olguların uzun dönem takiplerinde komşu segment dejenerasyon oranı radyolojik olarak \%50 ile \%60 arasında görülmüştür. Baba ve ark. [24] ise 100 hastalık servikal miyelopati nedeni ile ASDF uygulanmış serilerinde ameliyat sonrası dönemde ortalama 8,5 yıllık takip süresinde, hastaların \%25'inde yeni gelişen spinal kanal darlığı gözlemlemişlerdir. 
Komşu segment hastalığının, servikal dejeneratif omurga hastalığının doğal seyri olduğu, cerrahiden bağımsız geliştiği görüşü de bir başka bakış açısıdır. Ishihara ve ark. [25] yapmış oldukları çalışmada 38 ile 57 yaş arası 112 hastalık serinin, ortalama 9,4 yıllık takiplerinde yapılan radyolojik tetkiklerinde (MR, miyelografi) $\mathrm{KSH}$ olan olgularda dura basısının daha sık görüldüğünü belirtmişlerdir. Çalışmada, 112 hastadan 19 (\%17)'unda KSH görülürken, en sık olarak C3-4 (\%13,3) ve C4-5 (\%13) segmentlerinde semptomatik $\mathrm{KSH}$ tespit etmişlerdir. Ameliyat sonrası takiplerinde ise 5 yılda \%89, 10 yılda \%84, 17 yılda \%67 hastada KSH gelişmediğini tespit etmişlerdir. İlk cerrahiden sonra $\mathrm{KSH}$ ile ilgili ortalama semptom gelişme süresini ise $6,5 \mathrm{yıl}$ olarak belirtmişlerdir. Bu çalışmalar da kesin olamamakla birlikte bize, $\mathrm{KSH}$ etiyolojisinde yaş ile beraber oluşan dejeneratif sürecin etkisinin yanında ameliyat öncesi dönemde klinik şikayet ya da bulgu oluşturmayan segmentlerde var olan dejenerasyonların ameliyat sonrası dönemde $\mathrm{KSH}$ nedeni olabileceğini düşündürmektedir.

Bu çalışmalarda yer alan hastaların çoğunun genç yaşta olması ve uzun dönem takiplerinde komşu segmentlerde gelişen dejenerasyon ve buna bağlı problemler neticesinde, literatürde ilk olarak 1960 'lı yıllarda tarif edilen disk protezi kavramı 2000'li yılların başında gelişen teknoloji ile beraber son halini almış ve klinik kullanıma girmiştir. Sonraki yıllarda yapılan birçok karşılaştırmalı çalışmada da füzyon ve artroplasti tekniği incelenmiştir. Verma ve ark. [26] ASDF ile total disk artroplastisi (TDA) yaptıkları olgularda ameliyat sonrası dönemde $\mathrm{KSH}$ gelişmesi ile ilgili meta-analizde 6 randomize karşılaştırmalı çalışmayı incelemişlerdir. Bu çalışmaların toplamında 1110 hastanın verileri incelenmiş olup sonuçta ASDF ile TDA yapılan hastalar arasında KSH gelişimi açısından fark tespit edilmemiştir. Boselie ve ark. [27] yapmış oldukları incelemede, toplam 2400 hasta verileri değerlendirilmiş olup ASDF ve TDA teknikleri ile tek seviye servikal diskektomi yapılan hastalar karşılaştırıımış ve $\mathrm{KSH}$ gelişimi açısından istatistiksel olarak iki teknik arasında anlamlı fark bulunmamıştır. Ancak artroplasti yapılan segmentte hareket genişliğinde istatistiksel olarak anlamlı derecede artış olduğunu belirtmişlerdir.
Yapılan tüm bu çalışmalar ve meta-analizler incelendiğinde KSH'nın etiyolojisinde cerrahi tekniğin etkili bir faktör olmadığı sonucuna varmaktayız. Ayrıca ideal disk protezi halen üretilememiş olup, disk protezlerinin uzun dönemde füzyona uğrama durumları net olarak bilinmemektedir [27]. Uzun dönemde yapılacak olan prospektif çalışmalarla bu konuya açıklık getirileceği düşünülmektedir. Bizim yapmış olduğumuz ortalama 16 ay süreli takiplerde de PEEK kafes ile ASDF yapılan 142 hastadan yirmisinde $(\% 14,1)$ komşu segment dejenerasyonu görülürken, bu hastalardan 6 'sının $(\% 4,2)$ semptomatik olduğu ve bunlardan ikisinin $(\% 1,4)$ ameliyat edildiği saptanmıştır. Hastaların ortalama takip süreleri göz önüne alındığında yıllık insidansın \%1,05 olduğu görülmektedir. Literatür ile kıyaslandığında oranların daha düşük olması takip süremizin kısalığı ile ilişkili olabileceğinden daha uzun soluklu yapılacak olan takiplerde bu oranın artabileceğini düşünmekteyiz.

Sonuç olarak, füzyonsuz diskektomi, füzyon ile birlikte segmental fiksasyon (anterior servikal plak) ve servikal vertebranın dinamik durumuna daha uyumlu olması amaçlanan ve gelişen teknolojiler ile her geçen yıl daha da çok araştırma odağı olan disk artroplastisi gibi yeni yöntemler mevcuttur. Servikal sagittal aksın düzeltilmesinde, ağrı ve güç kaybı gibi hastanın yaşam kalitesini azaltacak durumların iyileştirilmesinde son 50 yıldır etkin, uygulanabilir ve finansal anlamda daha ekonomik bir yöntem olan ASDF uygulamasının önemine değindiğimiz çalışmamız, SDH'nin tedavisinde eski ve yeni birçok yöntemle karşılaştırıldığında, ASDF yönteminin günümüzde altın standart tedavi olduğunu desteklemektedir.

Çıkar ilişkisi: Yazarlar çıkar ilişkisi olmadığını beyan eder.

\section{Kaynaklar}

1. Wong JJ, Côté P, Quesnele JJ, Stern PJ, Mior SA. The course and prognostic factors of symptomatic cervical disc herniation with radiculopathy: a systematic review of the literature. Spine J 2014;14:1781-1789. https:// doi.org/10.1016/j.spinee.2014.02.032

2. Kondo K, Molgaard CA, Kurland LT, Onofrio BM. Protruded intervertebral cervical disk: incidence and affected cervical level in Rochester, Minnesota, 1950 through 1974. Minn Med 1981;64:751-753. 
3. Vavruch L, Hedlund R, Javid D, Leszniewski W, Shalabi A. A prospective randomized comparison between the cloward procedure and a carbon fiber cage in the cervical spine: a clinical and radiologic study. Spine (Phila Pa 1976) 2002;27:1694-1701. https://doi. org/10.1097/00007632-200208150-00003

4. Hirsch C. Cervical disk rupture: diagnosis and therapy. Acta Orthop Scand 1961;30:172-186. https:// doi.org/10.3109/17453676109149538

5. Caspar W, Barbier DD, Klara PM. Anterior cervical fusion and Caspar plate stabilization for cervical trauma. Neurosurgery 1989;25:491-502. https://doi. org/10.1097/00006123-198910000-00001

6. Hilibrand AS, Carlston GD, Palumbo MA, Jones $\mathrm{PK}$, Bohlman HH. Radiculopathy and myelopathy at segments adjacent to the site of a previus anterior cervical arthrodesis. J Bone Joint Surg Am 1999;81:519-528. https://doi.org/10.2106/00004623199904000-00009

7. Mummaneni PV, Burkus JK, Haid RW, Traynelis VC, Zdeblick TA. Clinical and radiographic analysis of cervical disc arthroplasty compared with allograft fusion: a randomized controlled clinical trial. J Neurosurg Spine 2007;6:198-209. https://doi. org/10.3171/spi.2007.6.3.198

8. Watters WC, Levintal R. Anterior cervical discectomy with and without fusion. Results, complications, and long-term follow-up. Spine (Phila Pa 1976) 1994;19:2343-2347. https://doi.org/10.1097/00007632199410150-00016

9. Vernon H, Mior S. The Neck Disability Index: a study of reliability and validity. J Manipulative Physiol Ther 1991;14:409-415.

10. Ware JE, Snow KK, Kosinski M, Gandek B. SF-36 Health Survey: Manual and Interpretation Guide. Boston, Massachusetts, The Health Institute, New England Medical Center, 1993.

11. Harrison DE, Harrison DD, Cailliet R, Troyanovich SJ, Janik TJ, Holland B. Cobb method or Harrison posterior tangent method: which to choose for lateral cervical radiographic analysis? Spine (Phila Pa 1976) 2000;25:2072-2078. https://doi.org/10.1097/00007632200008150-00011

12. Grob D, Frauenfelder $\mathrm{H}$, Mannion AF. The association between cervical spine curvature and neck pain. Eur Spine J 2007;16:669-678. https://doi.org/10.1007/ s00586-006-0254-1

13. Gore DR, Sepic SB, Gardner GM, Murray MP. Neck pain: a long-term follow-up of 205 patients. Spine 1987;12:1-5 https://doi.org/10.1097/00007632198701000-00001

14. Kelsey JL, Githens PB, Walter SD, et al. An epidemiological study of acute prolapsed cervical intervertebral disc. J Bone Joint Surg Am 1984;66:907914. https://doi.org/10.2106/00004623-19846606000011
15. Abd Alrahman N, Dokmak AS, Abou Madawi A. Anterior cervical discectomy (ACD) versus anterior cervical fusion (ACF), clinical and radiological outcome study. Acta Neurochir (Wien) 1999;141:1089-1092. https:// doi.org/10.1007/s007010050487

16. Xie JC, Hurlbert RJ. Discectomy versus discectomy with fusion versus discectomy with fusion and instrumentation: a prospective randomized study. Neurosurgery 2007;61:107-117. https://doi. org/10.1227/01.neu.0000279730.44016.da

17. Savolainen S, Rinne J, Hernesniemi J. A prospective randomized study of anterior single-level cervical disc operations with long-term follow-up: surgical fusion is unnecessary. Neurosurgery 1998;43:51-55. https://doi. org/10.1097/00006123-199807000-00032

18. van den Bent MJ, Oosting J, Wouda EJ, van Acker $\mathrm{RE}$, Ansink BJ, Braakman R. Anterior cervical discectomy with or without fusion with acrylate: a randomized trial. Spine 1996;21:834-839. https://doi. org/10.1097/00007632-199604010-00011

19. Wirth FP, Dowd GC, Sanders HF, Wirth C. Cervical discectomy. A prospective analysis of three operative techniques. Surg Neurol 2000;53:340-348. https://doi. org/10.1016/s0090-3019(00)00201-9

20. Smith GW, Robinson RA. The treatment of certain cervical - spine disorders by anterior removal of the intervertebral disc and interbady fusion. J Bone Joint Surg Am 1958;40:607-624.

21. Samartzis D, Shen FH, Lyon C, Phillips M, Goldberg $\mathrm{EJ}, \mathrm{An}$ HS. Does rigid instrumentation increase the fusion rate in one-level anterior cervical discectomy and fusion? The Spine Journal 2004;4:636-643. https:// doi.org/10.1016/j.spinee.2004.04.010

22. Goffin J, van Loon J, Van Calenbergh F, Plets C. Long-term results after anterior cervical fusion and osteosynthetic stabilization for fractures and/ or dislocations of the cervical spine. J Spinal Disord 1995;8:500-508.

23. Teramoto $T$, Ohmori $K$, Takatsu $T$, Inoue $H$, Ishida $Y$, Suzuki K. Long-term results of the anterior cervical spondylosis. Neurosurgery 1994;35:64-68. https://doi. org/10.1227/00006123-199407000-00010

24. Baba H, Furusawa $\mathrm{N}$, Imura $\mathrm{S}$, Kawahara $\mathrm{N}$, Tsuchiya $\mathrm{H}$, Tomita $\mathrm{K}$. Late radiographic findings after anterior cervical fusion for spondylotic myeloradiculopathy. Spine 1993;18:2167-2173. https:// doi.org/10.1097/00007632-199311000-00004

25. Ishihara $\mathrm{H}$, Kanamori $\mathrm{M}$, Kawaguchi $\mathrm{Y}$, Nakamura $\mathrm{H}$, Kimura T. Adjacent segment disease after anterior cervical interbody fusion. Spine J 2004;4:624-628. https://doi.org/10.1016/j.spinee.2004.04.011

26. Verma K, Gandhi SD, Maltenfort M, et al. Rate of adjacent segment disease in cervical disc arthroplasty versus single-level fusion: meta-analysis of prospective studies. Spine (Phila Pa 1976) 2013;38:2253-2257. https://doi.org/10.1097/BRS.0000000000000052 
27. Boselie TFM, Willems PC, van Mameren $H$, de Bie R, Benzel EC, van Santbrink H. Arthroplasty versus fusion in single-level cervical degenerative disc disease. Cochrane Database Syst Rev 2012:CD009173. https:// doi.org/10.1002/14651858.CD009173.pub2

*Türk Nöroşirürji Derneği 30. Ulusal Kongresinde, EPS-458 numarası ile elektronik poster sunumu olarak kongre kitapçığında yer almıştır

Etik kurul onayı: Bu çalışma 2019 yılından önce yapılmış retrospektif bir çalışma olması sebebi ile etik kurul onayı alınmamıştır.

\section{Yazarların makaleye olan katkıları}

Ü.A.D. ve Ö.H.E. çalışmanın ana fikrini ve hipotezini kurgulamışlardır. Ü.A.D. teoriyi geliştirmiş, gereç ve yöntem bölümünü düzenlemişdir. Sonuçlar kısmındaki verilerin değerlendirmesini Ü.A.D. yapmıştır. Makalenin tartışma bölümü Ü.A.D. tarafından yazılmış, Ö.H.E. gözden geçirip gerekli düzeltmeleri yapmış ve onaylamıştır. Ayrıca tüm yazarlar çalışmanın tamamını tartışmış ve son halini onaylamıştır. 